\title{
Rock Slope Stability Problems in Wadi Quaz-Dam Site No. 2, Jeddah-Saudi Arabia
}

\author{
Ali Abdullah M. Alzahrani \\ Department of Geological Engineering, King Abdullaziz University, Jeddah, Saudi Arabia \\ Email: aaalzahrani7@kau.edu.sa \\ Received 21 October 2015; accepted 17 November 2015; published 20 November 2015 \\ Copyright @ 2015 by author and Scientific Research Publishing Inc. \\ This work is licensed under the Creative Commons Attribution International License (CC BY). \\ http://creativecommons.org/licenses/by/4.0/ \\ c) (i) Open Access
}

\section{Abstract}

The present investigation deals with the engineering geological studies of soil and rock masses in the Wadi Quaz area-Dam No. 2, East of Jeddah. Wadi Quaz area-Dam No. 2, East of Jeddah, Saudi Arabia often faces floods during rainy seasons, so it is so urgent to investigate the area before building any dam or preventing water from flow. Preventing water from flow will produce new dangerous factors such as uplift force which may cause the dam failure. To have a better understanding of the factors that may affect the slope stability, many rock slope locations are observed in detail to assess the effect of discontinuities formed in the rock masses. Fieldwork and Laboratory tests were carried out on soil and rocks. Soils included identification of soil type using unified soil classification system, permeability, water content and field density were done for soils. Rocks include identification of physical and mechanical properties such as: rock type, degree of weathering, rock strength, $R Q D$, joint spacing measurements, and geometric properties (Dip, and Dip direction). Different methods were used to evaluate the potential failure in the studied area depending on rock mass rating and slope stability analysis. The well-known classification of rock masses titled Rock Mass Rating system [1] was used for categorizing the rock masses in the studied area besides slope mass rating [2] which would help to estimate the rock stability. The kinematical analysis was applied to investigate the potential failure mode which might occur in the dam abutments. This paper will provide the stability of dam abutments in both summer season and winter season besides general estimation of the seepage problems related to the soil and according to its permeability.

\section{Keywords}

Jeddah, USC, RMR, Dams, Slope Stability, Discontinuity, Kinematic Approach, SMR, Wadi Quaz-Dam No. 2

\section{Introduction}

"Many dams are multipurpose and most dams have at least some flood mitigation effect in addition to their pri- 
mary purpose" [3]. So it is so important to know the size of the problem which may occur around the dam site whether in the soil section or with the rock section. The reason of site investigation of soil and rock is to increase the dam damage mitigation.

Jeddah is located on the Eastern shore of the Red Sea, between latitudes $21^{\circ} 46^{\prime} 53^{\prime \prime} \mathrm{N}$ to $21^{\circ} 46^{\prime} 79^{\prime \prime} \mathrm{N}$ and Longitude $39^{\circ} 05^{\prime} 19^{\prime \prime} \mathrm{E}$ to $39^{\prime} 04^{\prime} 91^{\prime \prime} \mathrm{E}$ as shown in Figure 1, the study area of Wadi Quaz-Dam No. 2 is located between longitudes $39^{\circ} 23^{\prime} 15.36 " \mathrm{E}$ to $39^{\circ} 23^{\prime} 41.28^{\prime \prime} \mathrm{E}$ and latitudes $21^{\circ} 30^{\prime} 36^{\prime \prime} \mathrm{N}$ to $21^{\circ} 30^{\prime} 10.8^{\prime \prime} \mathrm{N}$ as can be seen in Figure 2. It is accessible through Alharamin road toward Al Madinah city. Geological investigations are carried out; the results show that studied area mostly consists of Ande site, and often faces rock slope failures during rainy seasons beside huge flood risks, so it is so important to make sure that is this dam will be strong against water according to the abutment strength and soil permeability.

Many residences houses are located in the same direction of Wadi Quaz. The residences are located near the dam site which have potential hazard of movement, instability and flood. Failure of these rock slopes can lead to da

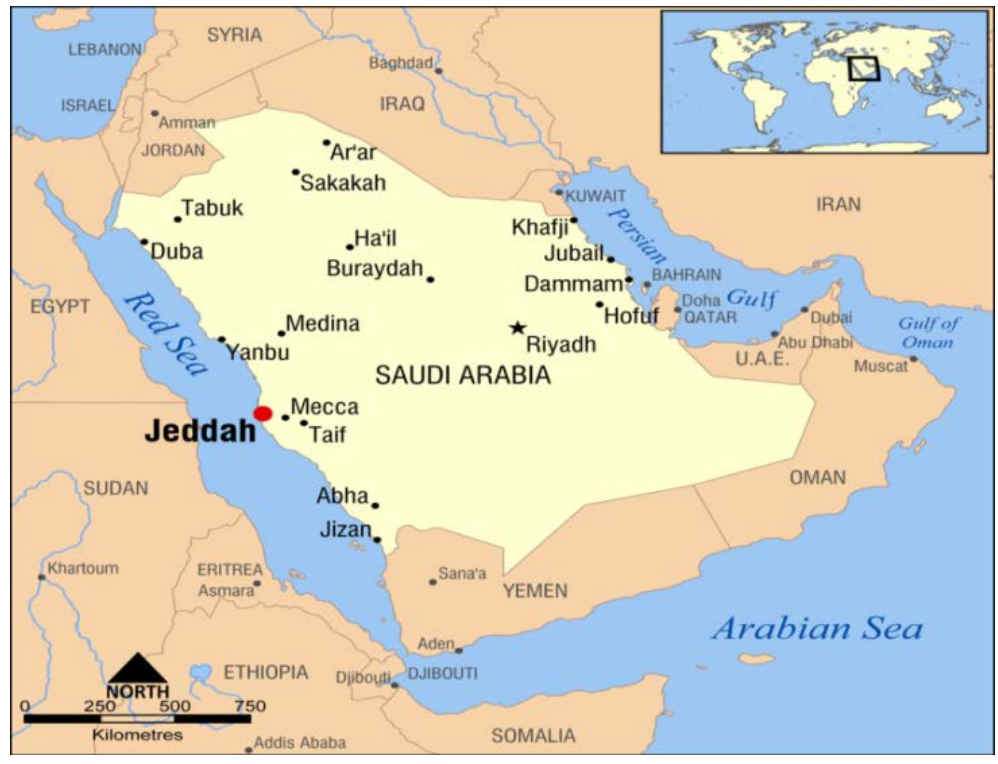

Figure 1. Geographic map showing Jeddah city-Saudi Arabia.

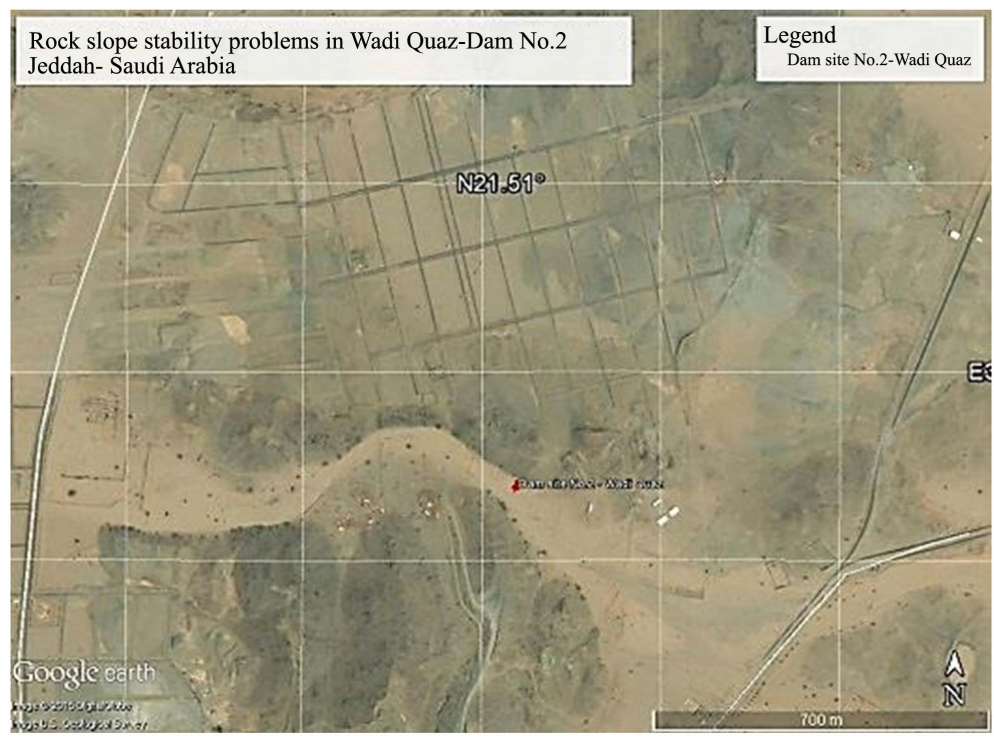

Figure 2. Google map on investigated Dam site (location of dam is indicated by Red Cross sign). 
maging results and will have a deep economic and social impact on the society of this area. Also the slope failure can be very harmful for infrastructures located in East of Jeddah such as roads and bridges. Flood disaster occurred in Jeddah in 2009 claimed the lives of more than 100 death between citizen and resident and many other losses [4].

The main purpose of this study is to evaluate the dam site No. 2, at Wadi Quaz, East of Jeddah by studying the physical and mechanical properties of soil and rock besides investigating the two abutments from each side of the dam whether south abutment or north abutment can be seen in Figure 3 and Figure 4.

Studying the dam abutments cut slopes by analyzing them using kinematic approach, Slope Mass Rating (SMR) and Rock Mass Rating (RMR), the potential failure modes of them are identified and the condition of abutments slopes stability is determined.

\section{Geology of the Area}

Jeddah area is situated principally on the coastal plain of the Red Sea and extends into the adjacent hills. These

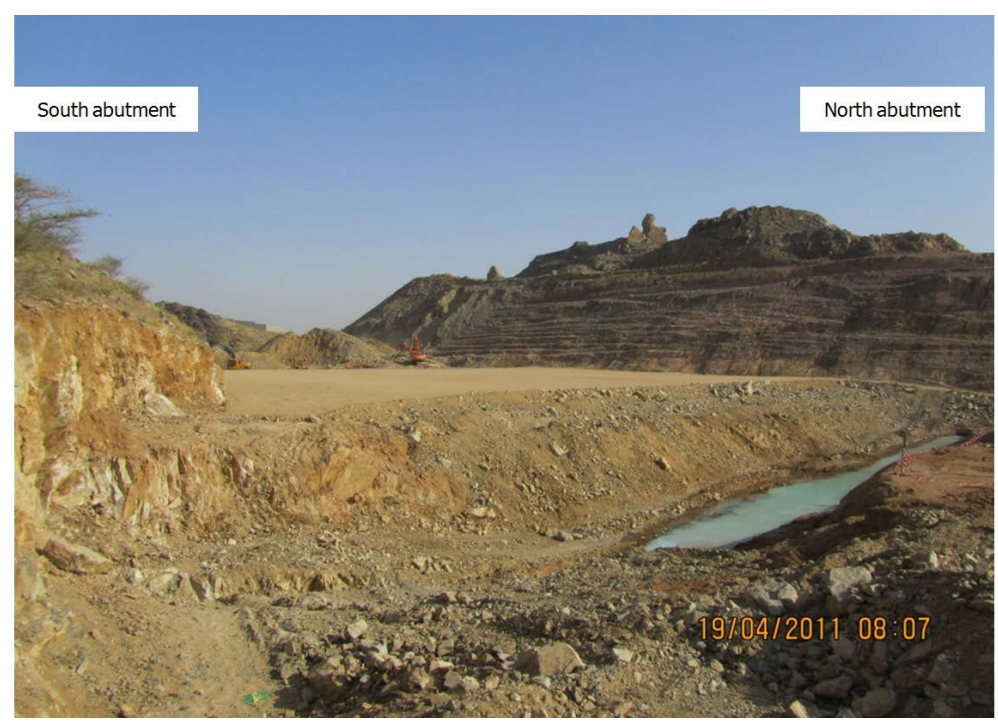

Figure 3. A view of the Location on investigated Dam site.

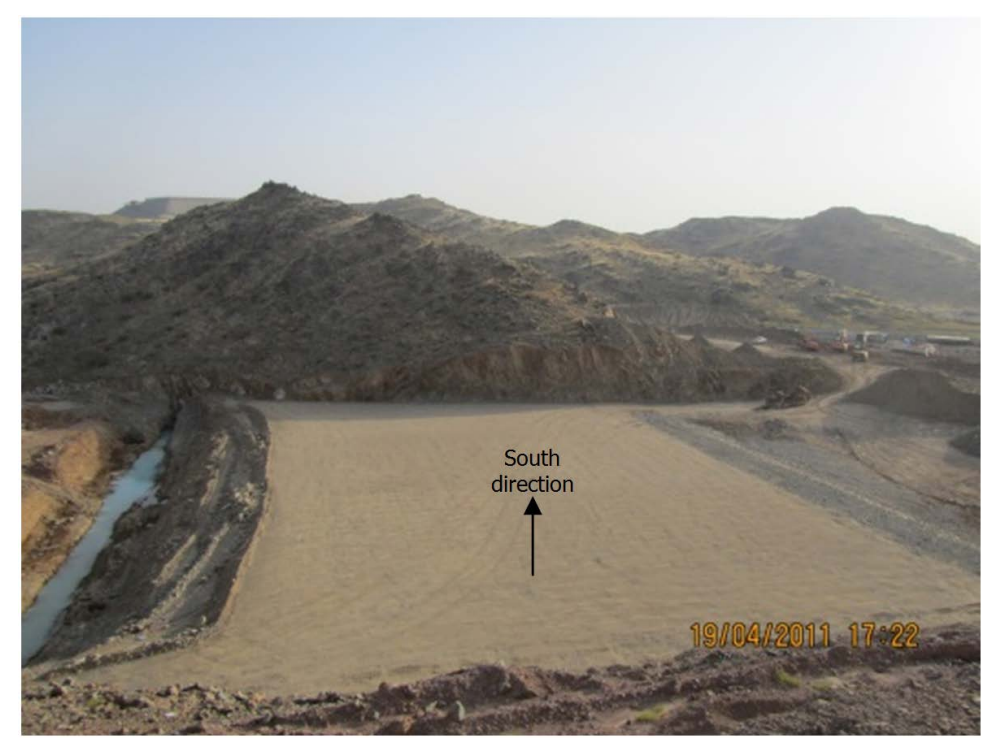

Figure 4. Another view of the Location on investigated Dam site (Elongated trench from south to north on the left). 
hills are composed mainly of Precambrian stratiform and plutonic rocks and subsidiary Tertiary sedimentary rocks [5]. The basement rocks in the area were classified by Moore and Al-Rehaili (1989) as a part of Makkah quadrangle, which consist of the following:

- The Precambrian stratiform rocks are of the Madrakah formation which belongs to the Samran group and the younger Nabah formation of the Fatima group. The Nabah formation crops out in the southeastern part of the area and consists of greywacke, siltstone, limestone, and felsic to mafic volcanic rocks.

- The sedimentary Miocene Abhor formation crops out in the extreme north of Jeddah city area beneath the Neogene Hammah basalt of the Rahat group. Tertiary rocks containing gypsum and halite as much as $40 \mathrm{~m}$ thick underline the coastal plain.

- The Quaternary deposits cover extensive areas in Jeddah city and surroundings area, principally on the coastal plain, but also in the large inland drainage basins. These deposits can be divided into three units. The oldest is the raised reef limestone, the undifferentiated alluvial, alluvial, talus and Aeolian deposits, and finally the sabkha deposits.

- In the western part of the Jeddah city area, the Quaternary deposits of the coastal plain consist of raised coral reef limestone, marine sediments, and sabkha deposits.

- In the east region, sand, gravel, and low terrace deposits are predominant. Wadi sand and gravel and local talus deposits and sand dunes occur in the eastern hills.

Wadi Quaz is dry throughout in the all-day of the year, only during the rainy season as winter season, dense water flows on the surface temporarily.

\section{Site Investigation}

The rock in the studied area has been divided into six stations. In each station has been identified the rock type, state of weathering, nature and characteristics of discontinuity surfaces has been identified. Some of instep tests have been conducted such as the joint wall compressive strength by using the Schmidt hammer (L-type). Samples were collected for the petrographic analysis. The soil in the studied area has been divided into six stations three of them upstream and the other three downstream to determine the field density, sieve analysis and water content of the samples collected from the trial pits besides one cross section downstream.

\section{Field Survey}

The area of interest should be first divided into stations (locations) on the basis 20 meters grids which might be helpful to produce more precision answer and accurate results. Then this station may be further subdivided into substations depending on the changes of the state of weathering for the same rock and soil type.

\subsection{Soil Survey}

The upstream and downstream soil in the studied area has been divided into six stations to determine the field density, sieve analysis and water content of the samples collected from the trial pits besides one cross section downstream as shown in Table 1. The surface and subsurface soils were classified using USC system.

\subsection{Rock Survey}

The studied locations were classified into six zones as can be seen in Figure 5. The quality of rock masses in the study area is ranging from poor quality to good quality rock mass. Engineering classification of rock masses is necessary to recognize rock mass condition, and divide the rock mass into groups of similar characteristics for engineering purposes.

To understand the impacts of the discontinuities on the rock abutments located at Wadi Quaz dam site No. 2, site investigations were applied in 2011 to collect the important Geometric properties of discontinuities such as: dip, dip direction, spacing, aperture, persistence, etc., compressive strength by using Schmitt hammer and types of rocks. Six locations were selected on the rock abutment located in both dam sides. The data in Table 2 and Table 3 were collected on the assumption of dry state during summer season.

\section{Data Analyses}

The collected data were processed by Dips Computer Software V.6 [6] to identify the potential failure modes of 


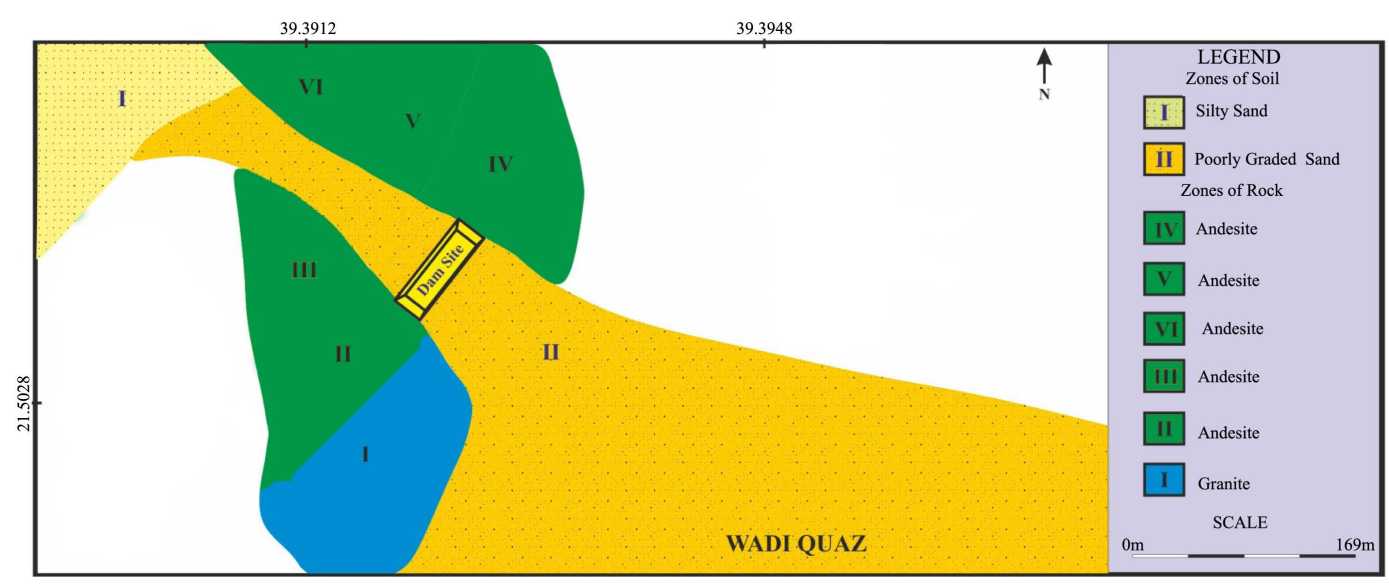

Figure 5. Geological map showing the rock types in both abutments.

Table 1. The results of D10, Concavity Coefficient (Cc) and other properties.

\begin{tabular}{|c|c|c|c|c|c|c|c|c|c|}
\hline \multicolumn{3}{|r|}{ Sample No. } & $\mathbf{D}_{10}(\mathrm{~mm})$ & $\mathbf{D}_{30}(\mathrm{~mm})$ & $\mathbf{D}_{60}(\mathrm{~mm})$ & Ll \% & Pl \% & Cc & $\mathbf{C u}$ \\
\hline & & I & 0.1645 & 0.3150 & 0.7202 & NV & NP & 0.84 & 4.38 \\
\hline & & II & 0.0943 & 0.1620 & 0.2788 & NV & NP & 1 & 2.96 \\
\hline & & III & 0.1299 & 0.1986 & 0.3266 & NV & $\mathrm{NP}$ & 0.93 & 2.51 \\
\hline & & IV & 0.0556 & 0.1158 & 0.2372 & $\mathrm{NV}$ & NP & 1.02 & 4.26 \\
\hline & & V & 0.1517 & 0.2375 & 0.5120 & NV & NP & 0.73 & 3.37 \\
\hline & & VI & 0.0350 & 0.0838 & 0.2241 & NV & NP & 0.89 & 6.40 \\
\hline & C-1 & Depth in meter $=1.13$ & 0.4654 & 1.0788 & 1.9922 & NV & NP & 1.25 & 4.28 \\
\hline Uूँ & $\mathrm{C}-2$ & Depth in meter $=0.56$ & 0.2385 & 0.8855 & 2.3469 & NV & NP & 1.40 & 9.84 \\
\hline ڤ్ & C-3 & Depth in meter $=0.28$ & 0.2786 & 1.5368 & 4.5458 & NV & NP & 1.86 & 16.31 \\
\hline 0 & C-4 & Depth in meter $=0$ & 0.3229 & 0.7421 & 1.5646 & $\mathrm{NV}$ & NP & 1.09 & 4.84 \\
\hline
\end{tabular}

Table 2. The geometric properties of discontinuities were collected at the studied area.

\begin{tabular}{|c|c|c|c|c|c|c|}
\hline $\begin{array}{ll} & \text { Station No. } \\
\text { Parameters } & \\
\end{array}$ & I & II & III & IV & $\mathbf{V}$ & VI \\
\hline UCS (MPA) & 279.90 & 269 & 300.82 & 265.28 & 214.40 & 344.40 \\
\hline RQD (\%) & 79.34 & 72.1 & 52.3 & 78.7 & 72.1 & 39.1 \\
\hline Joint Spacing (cm) & 13.3 & 19.4 & 21.5 & 13 & 25.8 & 18.6 \\
\hline Joint Persistence & $>20$ & $>20$ & $>20$ & $>20$ & $>20$ & $>20$ \\
\hline Aperture (mm) & 3 & 2.6 & 2.25 & 2.6 & 2.1 & 1.5 \\
\hline :을 & 7 & 7 & 5 & 5 & 5 & 3 \\
\hline Infilling & Hard fill $<5$ mm & Soft fill $<5 \mathrm{~mm}$ & Soft fill $<5 \mathrm{~mm}$ & Hard fill $<5 \mathrm{~mm}$ & Hard fill $<5 \mathrm{~mm}$ & Clean \\
\hline Weathering & W3 & W2-W3 & W2 & W2-W3 & W2 & W2 \\
\hline Ground Water & Dry & Dry & Dry & Dry & Dry & Dry \\
\hline Total RMR & 68 & 62 & 64 & 66 & 61 & 59 \\
\hline Class Number & II & II & II & II & II & III \\
\hline Rock Mass Quality & Good Rock & Good Rock & Good Rock & Good Rock & Good Rock & Fair Rock \\
\hline Rock Type & Granite & Andesite & Andesite & Andesite & Andesite & Andesite \\
\hline Abutments & & South Abutment & & & North Abutment & \\
\hline
\end{tabular}


the investigated slopes. The results from North abutment kinematic analysis indicates that there is no potential failure mode as can be seen in Figure 6. The results from south abutment kinematic analysis indicate that there is only one potential failure mode. Planar sliding is the most likely failure mode that may occur at south abutment. Some of the discontinuities are located in red shade that shows the potential planar sliding area as can be seen in Figure 7.

Table 3. The attitude of joint set in the studied area (Summer Season-Dry State).

\begin{tabular}{ccc}
\hline & Set No. & Dip/Dip direction \\
\hline \multirow{2}{*}{ South Abutment } & 1 & $45 / 025$ \\
North Abutment & 2 & $87 / 354$ \\
\hline
\end{tabular}
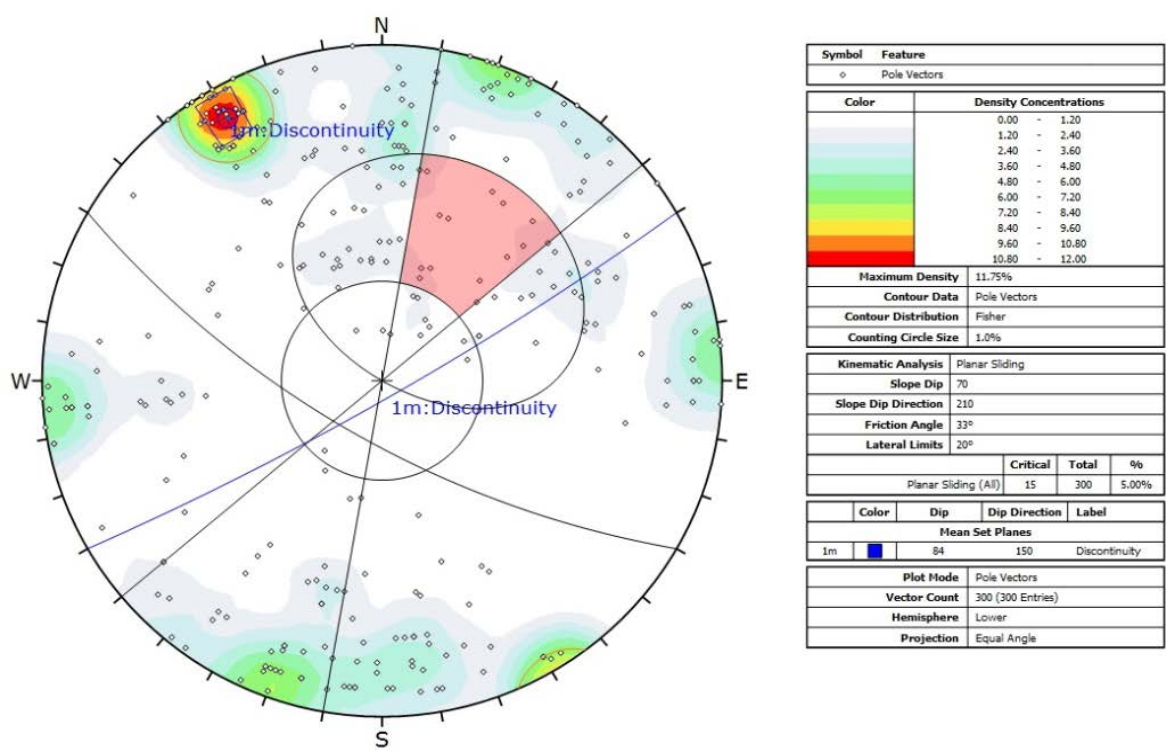

Figure 6. Analyze of planar sliding of North Abutment.
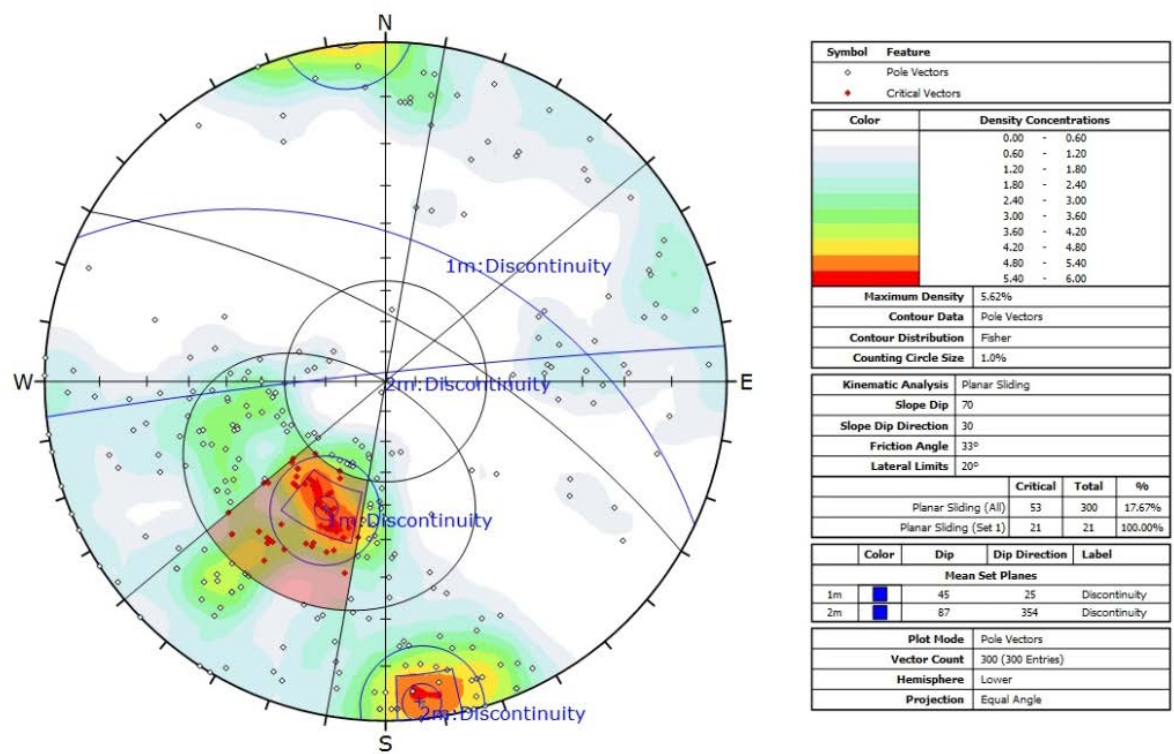

Figure 7. Analyze of planar sliding of South Abutment. 
Besides the kinematic analysis a SMR (Slope Mass Rating \& Rock Mass Rating) analysis was also conducted to assess the slopes. Table 4 indicates the results of RMR \& SMR analyses.

The results from SMR analyses show that the North abutment has the Stable condition in the dry state of summer season and the results from SMR analyses consistently show that the south abutment has the Partially Stable condition in the dry state of summer season. These results reflect that there will be a significant rock fall at south abutment.

The soil analysis according to Unified Soil classification has given value of $\mathrm{Cu}$ ranging between 2.51 to 16.53 with an average of 5.5 while the Cc value is ranging from 0.73 to 1.66 with an average of 1.048 , and the classification of soil in the study area is:

- Silty sand (SM) in two stations (station IV and VI);

- Poorly graded sand (SP) in four stations (I, II, III, and V).

And in subsurface soil (Cross Section):

- Poorly graded sand (SP) in 2 layers (C1 and C4);

- Well graded sand with gravel (SW with gravel) in 2 layer (C2 and C3).

In the other side the soil analysis according to Hazen equation and depending on the grain size distribution curve, the soil permeability $(\mathrm{K})$ could be determined using Hazen equation:

$\mathrm{K}=\mathrm{C} \times(\mathrm{D} 10)^{2}[7]$.

where:

- C is The Constant, Range from 100 to 150 ;

- D10 is the particle size corresponding to $10 \%$ finer on the cumulative particle-size distribution curve. The permeability of the soil in the study area according the Hazen equation is ranges from $0.1-0.18 \mathrm{~cm} / \mathrm{sec}$ to $21.66-32.49 \mathrm{~cm} / \mathrm{sec}$ show in Table 5. These results Shows huge permeability problem which might cause uplift force on the dam.

\section{Conclusions and Recommendations}

The results of kinematic analyses show that the rock is unstable under current conditions at the south abutment

Table 4. The SMR results at dry state on the summer season.

\begin{tabular}{ccccc}
\hline & Set No. & Dip/Dip direction & Average RMR/Description & Average SMR/Description \\
South Abutment & 1 & $45 / 025$ & $65 /$ Good Rock (II) & $59 /$ Partially Stable (III) \\
North Abutment & 2 & $87 / 354$ & & 62/Good Rock (II) \\
\hline
\end{tabular}

Table 5. The result of the permeability according to Hazen equation in the study area.

\begin{tabular}{cccccc}
\hline Soil Station No. & Sample No. & $\mathbf{D}_{\mathbf{1 0}}(\mathrm{mm})$ & \multicolumn{2}{c}{ Permeability $(\mathbf{K})(\mathrm{mm} / \mathrm{sec})$} \\
\hline I & I & 0.1645 & 2.71 & to & 4.06 \\
II & II & 0.0943 & 0.89 & to & 1.33 \\
III & III & 0.1299 & 1.6 & to & 2.53 \\
IV & IV & 0.0556 & 0.3 & to & 0.46 \\
V & V & 0.1517 & 2.3 & to & 3.45 \\
VI & VI & 0.035 & $0.12 \quad$ to & 0.18 \\
& C-1 & 0.4654 & 21.66 & to & 32.49 \\
Cross Section & C-2 & 0.2385 & 5.692 & to & 7.82 \\
& C-3 & 0.2786 & 7.83 & to & 11.74 \\
& C-4 & 0.3229 & $10.43 \quad$ to & 15.64 \\
\hline
\end{tabular}


and the potential failure mode is planar sliding. The SMR analysis result of this location indicates that the rock slope is class "III" under dry condition in the summer season, which means that the slope is partially stable, and which means that some blocks failure occasionally may occur at the south abutment, however it is so important to mitigate the unstable blocks and increase the stability of the other blocks by any type of stabilization methods. In the other side of North abutment, the results of kinematic analyses show that the rock is completely stable under current conditions and no potential failure mode is detected. The SMR analysis result of North abutment indicates that the rock slope is class "II" under dry condition in the summer season, which means that the slope is stable. On the assumption of winter season which may have high level of water upstream, the values of SMR is quiet similar if the comparison has been made between summer and winter season. Table 6 and Table 7 illustrate the comparison of wet and dry states results between these values of SMR, RMR and the Kinematic analysis.

Table 6. The assumption of dry state during the summer season.

\begin{tabular}{|c|c|c|c|c|c|c|c|}
\hline & \multirow{2}{*}{ Set No. } & \multirow{2}{*}{ Dip/Dip direction } & \multirow{2}{*}{$\begin{array}{c}\text { Average } \\
\text { RMR/Description }\end{array}$} & \multirow{2}{*}{$\begin{array}{c}\text { Average } \\
\text { SMR/Description }\end{array}$} & \multicolumn{3}{|c|}{ Kinematic Analysis } \\
\hline & & & & & Planar & Wedge & Toppling \\
\hline South Abutment & $\begin{array}{l}1 \\
2\end{array}$ & $\begin{array}{l}45 / 025 \\
87 / 354\end{array}$ & 65/Good Rock (II) & 59/Partially Stable (III) & Yes & No & No \\
\hline North Abutment & 1 & $84 / 150$ & 62/Good Rock (II) & 77/Stable (II) & No & No & No \\
\hline
\end{tabular}

Table 7. The assumption of wet state during the winter season.

\begin{tabular}{lccccccc}
\hline & Set No. & Dip/Dip direction & $\begin{array}{c}\text { Average } \\
\text { RMR/Description }\end{array}$ & $\begin{array}{c}\text { Average } \\
\text { SMR/Description }\end{array}$ & \multicolumn{2}{c}{ Kinematic Analysis } \\
\cline { 6 - 8 } South Abutment & 1 & $45 / 025$ & Planar & Wedge & Toppling \\
\hline North Abutment & 2 & $87 / 354$ & $57 /$ Fair Rock (III) & $50 /$ Partially Stable (III) & Yes & No & No \\
& 1 & $84 / 150$ & $55 /$ Fair Rock (III) & $62 /$ Stable (II) & No & No & No \\
\hline
\end{tabular}

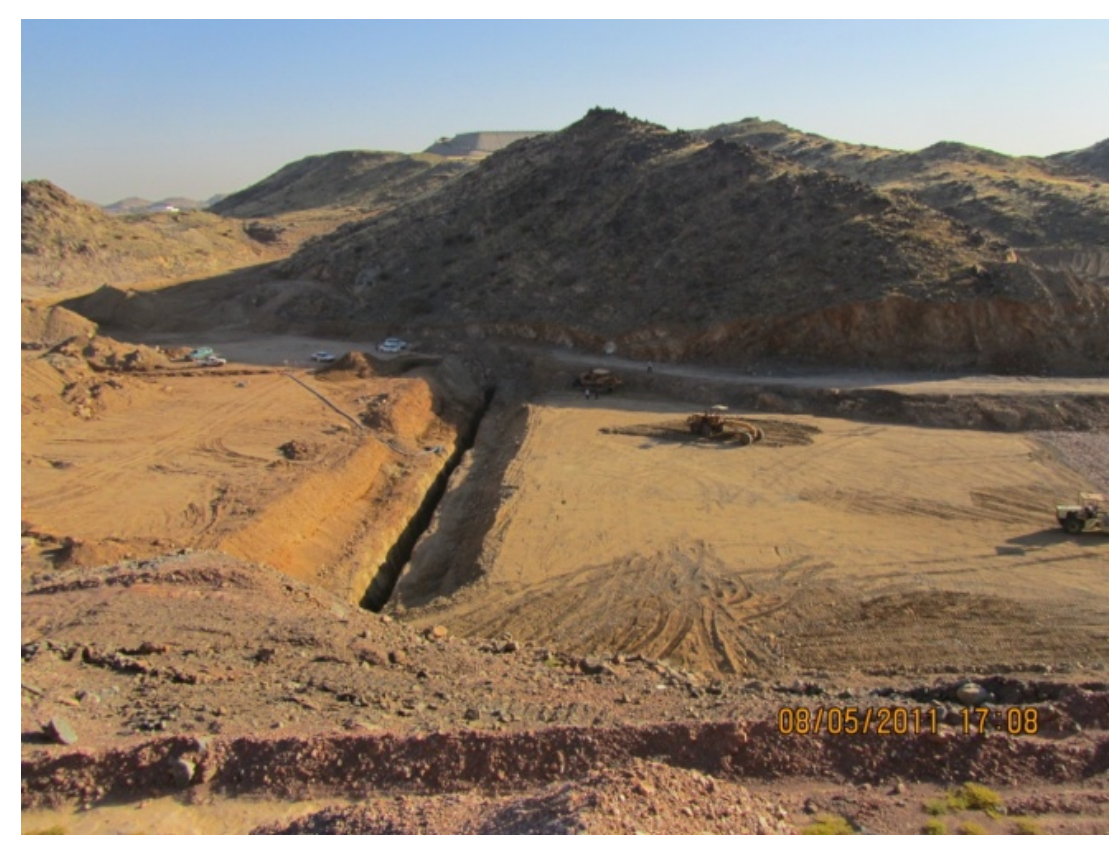

Figure 8. Photograph showing the elongated of trenching from North part of the study area to impede seepage of water. 


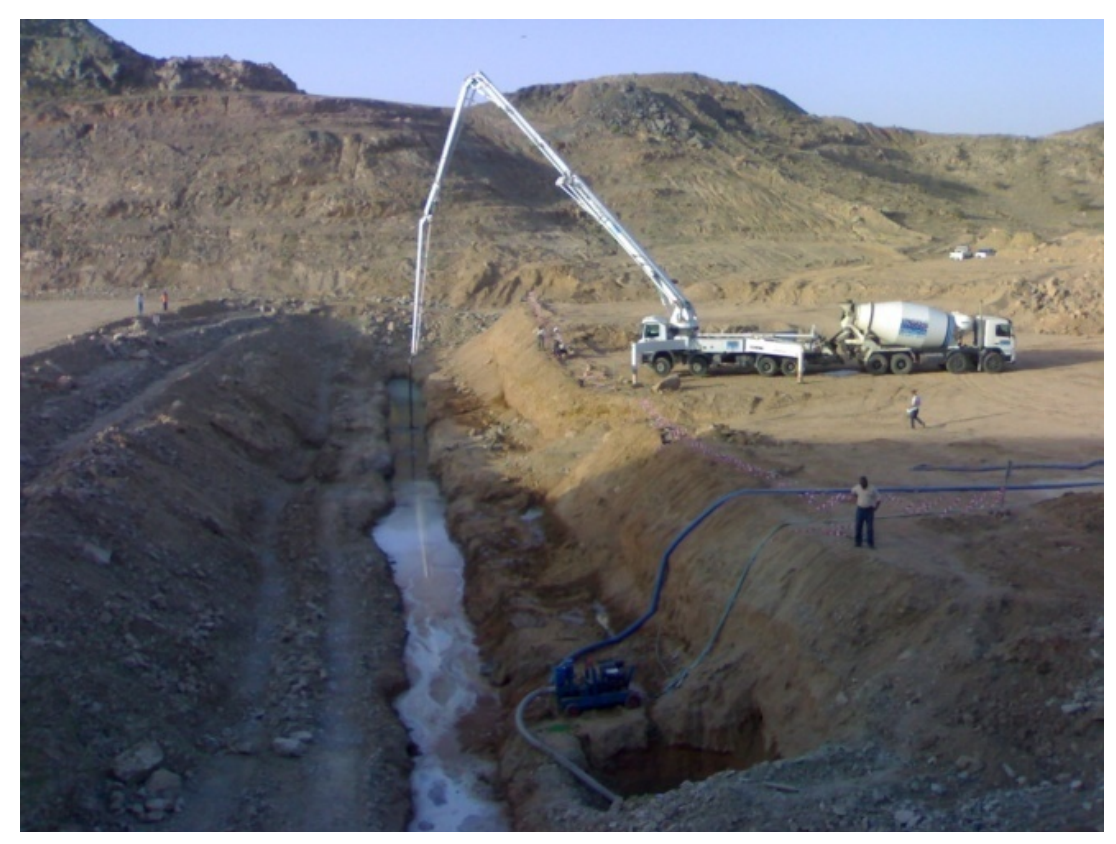

Figure 9. Photograph showing the grouting process at the study area to impede seepage of water (Chemical grouting by bentonite).

The soil classification in dam site shows that the soil has permeable soil and it surely will cause an uplift force. However, it is possible to avoid the permeability problem by building cut off wall as shown in Figure 8 and Figure 9.

\section{References}

[1] Bieniawaski, Z.T. (1976) Rock Mass Classification in Rock Engineering. Proceedings of the Symposium on Explore for Rock Engineering, Johannesburg, 1-5 November 1976, 97-106.

[2] Romana, M. (1985) New Adjustment Ratings for Application of Bieniawski Classification to Slopes. Proceedings of the International Symposium on the Role of Rock Mechanics in Excavations for Mining and Civil Works, International Society of Rock Mechanics, Zacatecas, 49-53.

[3] Woodward, R. (2005) Type of Dams. Richard Woodward's Web Site, Mar-2005.

http://members.optusnet.com.au/ engineeringgeologist/page6.html

[4] 2009 Jeddah Floods. Wikipedia, the Free Encyclopedia, 30-Nov-2014.

[5] Moore, T.A. and Al-Rehaili, M.H. (1989) Geologic Map of Makkah Quadrangle, Sheet 21D, Kingdom of Saudi Arabia: DGMR. Geoscience Map GM-107C, 1:250,000 Scale.

[6] Rocscience (2014) Dips. 04-Nov-2014. https://www.rocscience.com/rocscience/products/dips

[7] Hazen, A. (1892) Experiments upon the Purification of Sewage and Water at the Lawrence Experiment Station. 23 ${ }^{\text {rd }}$ Annual Report: Massachusetts State Board of Health, 428-434. 